\title{
Geopolitik, naturlige grænser og 'kartopolitik'
i Arktis
}

Jeppe Strandsbjerg Adjunkt, Department for Business and Politics, Copenhagen Business School, email: js.dbp@cbs.dk.

In this contemporary clash of scientific knowledges, legal regimes and offshore technologies, the uncertain spatialities of the

Circumpolar Region are being reconfigured (Powel 2008, 827).

Hvad sker der med vores forståelse af geopolitik i Arktis, hvis vi udfordrer antagelsen om, at geografien er en naturlig given baggrund for politik? Artiklen argumenterer for, at geopolitik ikke kun handler om konflikt mellem stater, men i lige så høj grad handler om at etablere en bestemt social geografi, som spiller sammen med en bestemt måde at organisere samfund på. Det kommer til udtryk i Arktis i kontroverser mellem stater og folkeret på den ene side og oprindelige folk og deres levevis på den anden.

\section{Introduktion}

Der har været skrevet meget om olie og geopolitik i Arktis gennem de senere år. Siden den famøse russiske flagplantning på havbunden ved Nordpolen i 2007 har det ikke skortet på dramatiske avisoverskrifter, som beskriver de Arktiske staters konkurrence om at kontrollere Nordpolen og de råstoffer, man forventer at kunne finde der. Under den kolde krig udgjorde Arktis en central geopolitisk arena for det amerikanske og russiske atomberedskab (Roucek 1983, 463). Nu har kombination af forventninger om store indtjeningsmuligheder og de uafklarede jurisdiktionsspørgsmål, der er opstået som følge af FNs Havretskonvention, ${ }^{2}$ genfødt det geopolitiske spøgelse i Arktis.

Pressen især - både den danske og den internationale - har fokuseret på konfliktpotentialet og geopolitikkens genfødsel. De arktiske stater derimod har været optagede af at nedtone konfliktpotentialet og i stedet understrege det fredelige samarbejde, der foregår i Arktis. Når diskus- sionen udfoldes som et spørgsmål om konflikt eller samarbejde, bliver geopolitik forstået som et forhold mellem stater. Og med et sådant fokus er der, som artiklen vil vise, ikke meget der tyder på, at Arktis ikke kan reguleres i fordragelighed mellem de arktiske stater. Imidlertid vil jeg argumentere for, at hvis vi undersøger de geografiske antagelser, der ligger til grund for den statsorienterede forståelse af geopolitik, så får vi forståelse af, at geopolitik i Arktis handler om mere end blot konkurrence mellem stater. Hvis vi udvider begrebet geopolitik og antager et mere socio-geografisk perspektiv, kan vi se, at kontroverserne om Arktis i høj grad handler om de geografiske præmisser for international ret og staters praksis overfor oprindelige folks livsform og deres rettigheder. Som sådan er artiklens budskab, at den geopolitiske kamp i Arktis ikke blot drejer sig om forholdet mellem de forskellige arktiske stater, men at der samtidig udspiller sig en konflikt mellem forskellige måder at forstå det geografiske rum på. Med andre ord bør vi inkludere spørgsmålet om, hvad geografi er, og hvordan det relaterer sig til et samfund - eller forskellige livsformer - for at få det fulde billede af arktisk geopolitik i dag.

Artiklen trækker på Kritisk Geopolitik (se fx Agnew \& Corbridge 1995; Ó Tuathail 1996), der har undersøgt den forståelse af forholdet mellem politik og geografi, som traditionelt har været implicit i International Politik disciplinens blik på verden. Den folkeretslige baggrund for, at geografi og kortlægning er blevet centrale størrelser i Arktis, ligger i $\$ 76$ i FNs Havretskonvention. Den giver mulighed for, at kyststater kan kræve ejerskab over ressourcer på og under havbunden, indenfor det der kaldes kontinentalsokkelen, ud til 350 sømil fra statens basis- 
linje, ${ }^{3}$ dvs. juridiske kystlinje. Populært sagt, har konventionens $\$ 76$ åbnet for suverænitetsspørgsmålet, om hvem der 'ejer' Nordpolen. Indenfor Havretskommissionens rammer bliver svaret på suverænitetsspørgsmålet styret af kortlægning og tilvejebringelse af data. Til at beskrive processen om kortlægning og ejerskab introducerer jeg begrebet 'kartopolitik', som refererer dels til en proces, hvor kortlægning spiller en afgørende rolle for det politiske, dels til de politiske konsekvenser af en bestemt måde at kortlægge geografisk rum på.

Det centrale ved kontinentalsokkelprocessen er, at man politisk er blevet enige om at lade landskabet afgøre jurisdiktionsspørgsmål. Ved at opstille geografiske betingelser for hvornår en stat kan gøre krav på en udvidet kontinentalsokkel, har man så at sige flyttet den geopolitiske kamp over i den videnskabelige arena. Derfor er det relevant at se på relationen mellem videnskab og politik og undersøge nærmere, hvordan den teknisk-videnskabelige del af kontinentalsokkelprojektet spiller sammen med de politiske processer. Nedenstående vil jeg diskutere, hvordan man kan betragte kontinentalsokkelprojektet som et forsøg på at etablere naturlige grænser. Denne diskussion vil trække på Bruno Latours videnssociologi, og den vil danne grundlag for den efterfølgende diskussion af forholdet mellem forskellige sociale geografier. Den primære skillelinje her går mellem det politiske spil mellem stater baseret på folkeretten på den ene side, og oprindelige folk på den anden. De oprindelige folk er her repræsenteret af Inuit Circumpolar Council (ICC), som eksplicit har formuleret en alternativ social rumforståelse i et forsøg på at vise, hvordan en tilsyneladende videnskabelig og objektiv rumforståelse i samspil med international lov udgør en trussel for Inuits måde at leve på.

Artiklen præsenterer et tværfagligt og kritisk argument, som søger at udvide forståelsen af, hvad geopolitik er og herigennem udvide forståelsen af, hvordan vi skal se på de geopolitiske processer, der finder sted i Arktis. Den eksisterende litteratur har en generel tendens til relativt isoleret at behandle enten udenrigs- eller sikkerhedsmæssige problemstillinger ( $\mathrm{fx}$ Jørgensen and Rahbek-Clemmensen 2009; Petersen 2009), teknisk videnskabelige problemstillinger (fx McDorman 2002; Macnab 2008; Proelss 2009), folkeretslige problemstillinger (fx Oude Elferink and Rothwell 2001; Jensen 2008), eller spørgsmål vedrørende oprindelige folk (fx McIver 1997; Shadian 2010). Folkeretten udgør ganske vist et fælles omdrejningspunkt for flere af disse emner, men det ændrer ikke ved, at der er en tendens til at holde de berørte temaer adskilt eller, at de geografiske antagelser sjældent udfordres.

Nærværende artikels bidrag er at knytte de nævnte dimensioner sammen gennem en kritisk analyse af de geografiske antagelser, der ligger til grund for dem. Det medfører en todelt analyse; den første del fokuserer på relationen mellem sikkerhed og videnskab; dvs. er det militære kapabiliteter eller videnskabelige data, der kommer til at afgøre suverænitetsspørgsmål i Arktis? Den anden del fokuserer på relationen mellem videnskab og kultur; dvs. hvilke implikationer har det videnskabelige rationale bag kontinentalsokkelprojektet set i forhold til de oprindelige folk i Arktis? Som sådan følger artiklen kritiske geopolitiske analyser af Arktiske forhold. ${ }^{4}$ Her har geografen Klaus Dodds kritisk analyseret international politik i både Antarktis (2002) og i Arktis (2010). Ligeledes har geograferne Phil Steinberg og Hannes Gerhardt beskæftiget sig med sammenhængen mellem geografi og suverænitets spørgsmål i Arktis (Gerhardt et al. 2010). Endelig skal Sanjay Chaturvedi (1996) nævnes, idet han var en af de første, der foretog en kritisk geopolitisk analyse af polarområderne. Denne artikel adskiller sig primært fra disse bidrag ved sit fokus på kortlægning og anvendelsen af begrebet kartopolitik.

Artiklen er opdelt i tre afsnit; først præsenterer jeg begrebet kartopolitik i relation til den kritiske geopolitik. Det leder frem til en diskussion af den statsfokuserede geopolitik i Arktis. Jeg argumenterer for, at begrebet kartopolitik giver en mere præcis begrebslig forståelse af suverænitetspolitik i Arktis ved at flytte fokus fra militær magt og sikkerhedspolitik til kortlægning og vidensproduktion i samspil med folkeret. Herefter kommer vi til analysens anden del, hvor jeg analyserer den geopolitik, der opstår ved et fokus på forskellige sociale rumligheder. På baggrund af interviews ${ }^{5}$, rapporter og policy-dokumenter identificerer jeg en øget spænding mellem en konventionel social geografi, der understøtter statspraksis og international ret på den ene side og en alternativ social geografi knyttet til Inuits oprindelige livsform på den anden. Konklusionen på den samlede analyse er, at det samspil mellem videnskab og international ret, som muliggør en fredelig løsning på suverænitetsspørgsmål mellem stater i Arktis, samtidig spiller en vigtig rolle i den grundlæggende geopolitisk konflikt mellem forskellige opfattelser af, hvordan politik og kultur relaterer sig til geografi.

\section{Geopolitik og Kartopolitik}

For mere end 15 år siden skrev geografen John Agnew i artiklen The Territorial Trap: "It has been the geographical division of the world into mutually exclusive territorial states that has served to define the field of study" (Agnew $\&$ Corbridge 1995, 78). Som Agnew selv udtrykker det, var artiklens hensigt at fremprovokere en diskussion af IP disciplinens skjulte geografiske antagelser (Agnew 2010, 779). Pointen er, at IP disciplinen, i hvert fald på det 
tidspunkt Agnew skrev, meget sjældent diskuterede geografi og rumbegrebet, men i stedet opererede med skjulte antagelser om geografien og gjorde territoriebegrebet til et uproblematisk geografisk fundament for stater. ${ }^{6}$ Som sådan var Agnews argument med til at bane vejen for det, der blev kendt som Kritisk Geopolitik.

Lidt forsimplet kan den kritiske geopolitik forstås på den måde, at man kritisk undersøger geo-siden af geopolitik. Begrebet består naturligvis af to led, og det defineres ofte som værende læren eller teorier om sammenhængen mellem geografi og politik. Men de oprindelige geopolitiske analyser, som begyndte at dukke op omkring forrige århundredeskifte, søgte at bruge geografien til at skabe et videnskabeligt grundlag for at studere staten og interstatslige forhold (Lund 2007). Geografien i den sammenhæng blev set som en naturgivet og objektiv størrelse. Således tilvejebragte geografien objektive betingelser for den førte politik. Men dette billede falder naturligvis sammen, hvis geografien ikke længere kan ses som en objektiv eller given størrelse. Således anfører den kritiske geopolitik, at bestemte former for geografisk tænkning hænger nøje sammen med en bestemt verdensopfattelse, som implicit leder til en bestemt politik.

Målet for den Kritiske Geopolitik er, at vi ved at dekonstruere den geografiske viden ændrer fundamentet for den førte politik. Vi er således inde at pille ved den naturvidenskabelige - eller objektive - rumforståelse, som ligger til grund for en rationalistisk tilgang til geopolitikken. Herved gøres geopolitik til en politisk praksis, som producerer en bestemt socio-politisk rumlighed. Og på den måde bliver det geografiske rum både analysens omdrejningspunkt samtidig med, at den optræder som et politisk og ikke et videnskabeligt fænomen. Opsummerende, har Gearoid Ó Tuathail defineret geopolitik som "the politics of writing global space" $(1996,18)$.

I sin oprindelige formulering var det eksplicit Ó Tuathails mål at komme ud over rene diskursive og meget abstrakte rumforståelse, som hidtil havde præget kritiske røster indenfor IP (1996, 170-78). Imidlertid har den Kritiske Geopolitik, som det er blevet påpeget af geografen Nigel Thrift (2000), bevæget sig i en diskursanalytisk retning, hvor geografien tenderer mod at blive reduceret til tekstlige konstruktioner. Og at se verden som et diskursivt fænomen hjælper ikke forståelsen af, hvorledes og dermed hvorfor geografien formes og spiller sammen med forskellige magtrelationer. I stedet anbefaler Thrift, at vi fokuserer på materiel praksis som kortlægning, opmåling, folketælling $\mathrm{mm}$. for at opnå en mere detaljeret forståelse af, hvordan rum bliver konstrueret (2000, 380-83).

Thrift er inspireret af den franske sociolog Bruno Latour, og jeg følger et lignende spor. Kritisk Geopolitik har stillet de rigtige spørgsmål, men der findes mere til- fredsstillende svar på spørgsmålet om geografiens sociale karakter ved at følge Latour end den Foucault inspirerede kritiske geopolitik. Latour er berømt for sin aktør-netværk teori (ANT) (1988; 1993; 2005). Hans perspektiv stiller spørgsmål om, hvorfor vi kan omtale klipper, floder, skær, øer, have osv. som geografi? Hvordan er alle disse fænomener blevet samlet i en enkelt videnskategori? Den grundlæggende pointe er, at det, der normalt betragtes som naturligt og objektivt, altid skal konstrueres socialt for at opnå den enhedskarakter, der gør, at man fx kan omtale geografisk rum som en lukket størrelse. Hans analytiske forskrifter følger en metode, der ligger tæt op ad etnografien. Man skal følge de enkelte aktører, der er involveret i de vidensprocesser, vi undersøger. Og den helt store forskel fra diskursanalysen er, at man med Latour ikke er begrænset til et diskursivt univers. Tværtimod åbnes analysen ved at inddrage den fysiske - eller den ikke-menneskelige i Latours terminologi (1999b, 174-215) - verden. Således omfatter rummet som social konstruktion både de fysiske genstande, vi normalt tænker på som naturlige, og de menneskelige praksisser, vi normalt tænker på som sociale. Ved at inddrage Latour's videnssociolog i den kritisk geopolitiske analyse kommer vi således frem til et fokus, der understreger videnskabelig praksis frem for diskursive videnskategorier.

At rummet er en social konstruktion er ikke noget nyt indenfor sociologien, men det har været et relativt marginaliseret tema. Allerede Emile Durkheim (1976) påpegede, at forskellige samfund konstruerede rum på forskellige måder. Vi skal altså være opmærksomme på, hvorledes bestemte rumopfattelser spiller sammen med forskellige samfundsformer. Dvs. den måde, det geografiske rum konstrueres som værende virkeligt gennem kartografi og andre repræsentative praksisser, er med til at bestemme, hvordan det geografiske rum kan organiseres rent politisk. Hermed bliver aktiviteter som kortlægning geopolitiske handlinger i sig selv. Begrebet kartopolitik dækker således over, hvordan rum bliver konstrueret og organiseret gennem videnskabelig praksis. Det handler ikke kun om at kortlægge og på anden vis tilvejebringe viden om det geografiske rum. Men måden det gøres på, er afgørende for, hvordan man kan organisere sig politisk. Det vil sige, at den måde, vi producerer viden på, allerede har kodet det geografiske rum på en måde, der sanktionerer nogle sociale organisationsformer og handlinger frem for andre.

Den rationalistiske og abstrakte rumopfattelse, som kom til udtryk gennem geometrisk - eller moderne kortlægning, udviklede sig i et tæt parløb med den moderne statsdannelse. Den moderne stat var således afhængig af en bestemt måde at kortlægge verden på; en måde som var baseret på en evne til at beregne og repræsentere 
rumlige koordinater ved hjælp af geometri (Strandsbjerg 2008; Crampton 2010; Elden 2010). Således handlede den klassiske geopolitik om stater og deres indbyrdes konkurrence. Men hvis vi med den kritiske geopolitik stiller spørgsmål ved den kartografiske selvforståelse og ved den naturgivne geografi, så handler den geopolitiske kamp ikke i første omgang om fordelingen af rum, men om hvordan rummet fremstår og spiller sammen med sociale organisationsformer. Herved udbredes det konfliktspektrum, vi kan få øje på ved en geopolitisk analyse.

\section{Geopolitik og naturlige grænser i Arktis}

Her i analysens første del fokuserer jeg på geopolitik som et spørgsmål om konflikt og samarbejde mellem stater. Jeg argumenterer ukontroversielt for, at samarbejde er et mere sandsynligt scenarie end konflikt. Målet med analysen er imidlertid at identificere de faktorer, som muliggør den fredelige løsning af suverænitetsproblemet. Faktorerne udgør et samspil mellem ideen om naturlige grænser, videnskab og politik. Dette leder frem til den anden del af analysen, der ser på videnskabens geopolitik.

Arktis udgjorde sammen med Antarktis de sidste uudforskede områder på kloden omkring det forrige århundredeskifte og udgjorde en scene for en ny etnologisk type opdagelsesrejser som Knud Rasmussen og Fridtjof Nansen (Hastrup 2010). På trods af deres rejser igennem de polare egne forblev Arktis et utilgængeligt område opfattet som et lukket land. Netop denne fornemmelse af lukkethed har været med til at gøre Arktis så interessant. Med overskrifter som 'Canada joins rush to the Arctic' og 'The Scramble for the seabed' har toneangivende aviser ${ }^{7}$ underbygget forestillingen om et uberørt område, som nu bliver tilgængelig for 'almindelig' politik og økonomisk praksis.

Kombinationen af smeltende havis, som åbner hidtidigt utilgængelige områder, og drømme om adgang til værdifulde råstoffer har sparket liv i forestillinger om en ny sort guldfeber og kampen om at komme først til det nye land. Netop derfor resonerede Artur Chilingarovs flagnedsætning på Nordpolen i sommeren 2007 med revitaliseringen af (post-)koloniale fantasier, hvor Chilingarovs ubåd havde erstattet den hvide opdagelsesrejsende, som ved flagplantning og andre symbolske suverænitetshandlinger gjorde krav på terra nullius. Det må have været tilfældet for Canadas (daværende - nu forsvarsminister) udenrigsminister, Peter MacKay: „This isn't the 15th century. You can't go around the world and just plant flags and say "We're claiming this territory" (citeret i Potts and Schofield 2008, 161). Det skal noteres, at Rusland ikke gjorde krav på Arktis, og som sådan var begivenheden ikke væsensforskellig fra amerikanernes flag på månen. Alligevel fulgte en del bastante meldinger efterfølgende.
På det retoriske plan har især Canada været relativt militaristiske og aggresive i deres udtalelser; premiereminister Stephen Harper kørte en meget udadfarende Arktisk linje i sin valgkamp. Sommeren 2007 udtalte han, at "Canada has a choice when it comes to defending our sovereignty in the Arctic; either we use it or we lose it, [and] make no mistake this government intends to use it. Because Canada's Arctic is central to our identity as a northern nation. It is part of our history and it represents the tremendous potential of our future". ${ }^{8}$ Samtidig har samtlige Arktiske kyststater annonceret, at de i en eller anden udstrækning vil opgradere deres militære tilstedeværelse; og igen fører Canada an med planer om at opbygge en bevæbnet isbryder flåde ${ }^{9}$ og forstærke deres 'Arctic Rangers'. Sidst har nyheden om, at de vil udstationere veteraner fra Afghanistan i Arktis, vækket mediernes interesse. ${ }^{10}$ Hertil er der kommet nogle efterhånden notoriske udtalelser fra Rusland, om at Arktis er Russisk, og man har set med bekymring på Ruslands hensigter (Petersen 2009). En typisk reaktion eksemplificeres af Pots og Schofield: "there is no doubt that symbolic planting of the Russian flag at the North Pole served to invest a legitimate process with geopolitical weight and significance. In particular, Russia's action was greeted with great fanfare in the domestic political context and illustrates a more robust posture internationally" (Potts and Schofield 2008, 158). Kombinationen af selvhævdende nationalistiske ytringer om retten til Arktis og opbygningen af militære kapabiliteter resonerer fint med den klassiske geopolitiks forståelse af en organisk sammenhæng mellem territoriet, nationen og evnen til at manifestere sin magt. ${ }^{11}$

Men som reaktion på den geopolitiske polemik og den sensationssøgende pressedækning tog Danmark og Grønland initiativ til et møde mellem de såkaldte Arctic 5 - de fem stater omkring Ishavet - som førte til Ililussat erklæringen i maj 2008, hvor alle stater erklærede deres tilslutning til et fredeligt samarbejde i Arktis indenfor Havretskonventionens rammer:

Notably, the law of the sea provides for important rights and obligations concerning the delineation of the outer limits of the continental shelf, the protection of the marine environment, including ice-covered areas, freedom of navigation, marine scientific research, and other uses of the sea. We remain committed to this legal framework and to the orderly settlement of any possible overlapping claims [...]. The five coastal states currently cooperate closely in the Arctic Ocean with each other and with other interested parties. This cooperation includes the collection of scientific data concerning the continental shelf, the 
protection of the marine environment and other scientific research. We will work to strengthen this cooperation, which is based on mutual trust and transparency, inter alia, through timely exchange of data and analyses (llulissat erklæringen 2008).

Det betyder, at alle lande erklærer, at de vil følge folkeretten og lade FNs kontinentalsokkelkommission afgøre de maritime grænser for nationale krav på retten til råstofudvinding. Ved at følge folkeretten har staterne samtidig erklæret, at de vil lade det geopolitiske spil om maritim jurisdiktion afgøre af kortlægning og videnskab frem for militær kapabilitet og magtpolitik.

Baggrunden for, at suverænitetsspørgsmål er blevet så vigtig del af Arktisk politik, ligger som nævnt i FNs Havretskonvention, hvor stater har mulighed for at gøre krav på det, der kaldes en udvidet kontinentalsokkel. Nøglen til det er $\$ 76$ i Havretskonventionen. Den definerer de omstændigheder, under hvilke stater kan udvide deres suveræne rettigheder til havs. UNCLOS introducerer begrebet Economic Exclusive Zone, eller økonomisk eksklusivzone (øez), som er knyttet til ideen om landes kontinentalsokler. Begrebet refererer til et område, hvor de enkelte stater suverænt kan kræve eneret til udnyttelse af råstoffer i undergrunden men kun har begrænset mulighed for at kontrollere sejlads fra andre lande. Imidlertid lever kontinentalsokkelen et dobbeltliv i konventionen, idet den både eksisterer som et juridisk og et geografisk ${ }^{12}$ objekt i loven. Alle kyststater har uden videre ret til en øez på 200 sømil fra deres basislinjer. Det vil sige, kontinentalsokkelen defineres juridisk uden at tage stilling til, hvordan landmassen rent faktisk fortsætter ud i havet. På den anden side giver $\$ 76$ mulighed for, i det omfang den geografiske kontinentalsokkel fortsætter længere end 200 sømil, at de respektive lande kan indgive krav til FN om at få anerkendt en udvidet kontinentalsokkelzone og hermed udvide deres jurisdiktion, hvad angår retten til at udvinde råstoffer. ${ }^{13}$ Her optræder kontinentalsokkelen som et geografisk fænomen. Det vil sige, at den almene kontinentalsokkel defineres juridisk, og spørgsmål om udvidelse bliver gjort til et spørgsmål om kortlægning og analyse af havbunden. Hermed bliver geografien, eller naturen om man vil, kriteriet for at udvide sine grænser. Det betyder principielt, at udvidelsen af grænser i Arktis bliver gjort til et spørgsmål om videnskabelig opmåling. Således bliver traditionel geo-politik afløst af karto-politik, hvor tilvejebringelsen af videnskabelige data afgør legitimeteten af suverænitetskrav.

Det staterne altså bliver enige om, når de erklærer deres tilslutning til UNCLOS' ord og ånd, er at lade geografien afgøre suverænitetsspørgsmål i forhold til at kontrollere de submarine ressourcer. Det rejser to spørgsmål. Det første går på, hvordan man lader naturen 'tale' i spørgsmålet om suverænitet. Det vender vi tilbage til i det følgende afsnit. Det andet spørgsmål går på, om staterne simpelthen rykker striden om Arktis over i den videnskabelige arena. Det er der ikke meget, der tyder på. Arbejdet med kortlægning og dataindsamling er i langt højere grad præget af samarbejde end af konflikter. Der er et udpræget og koordineret samarbejde mellem Canada og Danmark med hensyn til dataindsamling. Men også med Rusland er der samarbejde; ved den første danske LOMROG (Lomonosov Ridge of Greenland) ekspedition nord for Grønland i 2007 var man afhængig af hjælp fra en Russisk isbryder. Hvis Rusland ville have modsat sig indsamling af data til støtte for et dansk krav, kunne de blot have afslået at yde denne støtte. Ydermere kan det nævnes, at den anden LOMROG ekspedition 2009 havde følge af en russisk søopmåler. Og endelig, hvis man ser på det bredere politiske samarbejde i Arktis, spiller Rusland en toneangivende rolle i Arktisk Råd, hvor de presser på for et øget og bindende samarbejde i forbindelse med fx 'Search and Rescue' (SAR) beredskab. Det tyder således ikke på, at de Arktiske stater konkurrerer eller modarbejder hinanden i den videnskabelige arena. Hvis det er korrekt, så har de arktiske stater besluttet sig for, at lade landskabet tale i grænsespørgsmålet, og hermed rejses spørgsmålet hvordan man gør det.

Op igennem det 17. og 18. århundrede blev ideen om naturlige grænser mere udbredt i Europa (Sahlins 1989). Tankevækkende skete dette i takt med, at kartografien blev udviklet og blev et gradvist vigtigt redskab for politiske ledere og forståelsen af politisk territorium (Buisseret 1992; Strandsbjerg 2008; Biggs 1999). Det understreger, hvordan en specifik viden om det geografiske rum medierer eller betinger den måde rummet organiseres på politisk. Historisk var det fx først i det øjeblik, at Pyrenæerne kortlægges og erkendes som en sammenhængende bjergkæde, at den bliver udpeget som en naturlig grænse mellem Frankrig og Spanien (se Sahlins 1989 for en uddybning af argumentet).

Bjergkæder, floder mm. er tydelige objekter i landskaber, men den submarine kontinentalsokkel er ikke en man umiddelbart kan se eller erfare. Den juridiske kontinentalsokkel følger imidlertid den samme logik, om at man kan udpege naturligt forekommende landskabsformationer og bruge dem som en naturlig standard for grænsedragning. Og som konsekvens heraf overfører man den politiske beslutning om grænser til en videnskabelig analyse af landskabet. I modsætning til den klassiske geopolitiks forankring i den enkelte stat og dens interesser - hvorved de naturlige grænser blev mere naturlige for 
nogle stater end for andre - fremstår UNCLOS' betingelser for en udvidet kontinentalsokkel som en universel standard. Alle stater, der ratificerer UNCLOS, accepterer kontinentalsokkelen som en legitim betingelse for at kunne udnytte maritime ressourcer samtidig med at afgørelsen, om hvorvidt de naturgivne betingelser er til stede, er placeret hos et internationalt uvildigt organ under FN: Commission on the Limits of the Continental Shelf (CLCS).

For at koblingen mellem geografi, lov, og suverænitet kan lede til enighed om grænsedragning, kræver det imidlertid, at videnskaben kan tale med én stemme. Dette er nødvendigt for, at naturen kan fremstå som en standard. Det vil sige, at de videnskabelige opmålinger må fremstå entydige og alment accepterede. Dette synspunkt fremføres af en leder i Nature Geoscience, hvor det anerkendes, at geologien som faglig disciplin er blevet politiseret, og at det eneste modsvar er solide data: „if the science that underlies its recommendations stands the test of time will the shelves' outer limits established under UNCLOS be globally respected as the one and only valid demarcation line" (Proelss 2009, 309). Det viser, at muligheden for at trække legitime grænser er knyttet til ideen om, at der kan tilvejebringes objektiv viden om geografien. Hvis enten naturen i sig selv, eller repræsentationen af den, fremstår flertydig bliver videnskaben til gengæld politiseret.

Selv hvis vi accepterer, at et entydig videnskabeligt billede kan etableres, er der stadig usikkerhed indenfor havrettens præmisser. Potts \& Schofield skriver det meget direkte $(2008,163)$ :

The question of extended continental shelf claims in accordance with Article 76 of the LOSC is undoubtedly both legally and scientifically fraught and numerous "complexities and ambiguities" associated with Article 76 have been identified, as well as problems in respect of the way in which the Commission works.

Potts \& Schofield henviser her til, at der mangler standarder for, hvornår data er tilstrækkelige, og hvordan de skal analyseres og præsenteres. Herudover er der uklarhed omkring, hvilken juridisk status CLCSs anbefalinger har. Det er anbefalinger og har ikke bindende karakter (McDorman 2002).

Det er dog ikke usandsynligt, at de arktiske stater kan blive enige om at acceptere kommissionens anbefalinger som gældende. Canada, Danmark og Rusland har nemlig en fælles interesse $i$ at kunne dokumentere, at Lomonosov ryggen, som råstofmæssigt er den mest interessante, er en del af deres kontinentalsokler. Alligevel ligger der en mulighed for, at politiske hensyn, som ikke følger UNCLOS's ånd, kommer til at spille en rolle igen. Og der, hvor døren bliver genåbnet for geopolitik i klassisk forstand, er efter CLCS er kommet med sine anbefalinger. Det overses ofte, at det folkeretlige grundlag for at udvide kontinentalsokkelen, udelukkede går på en demarkation mellem internationalt farvand og en national jurisdiktion. Det omhandler altså en afmærkning af hvilke områder, der er fælles, og hvilke områder, der er nationale. Efter der er taget stilling til eventuelle udvidelser af kontinetalsokkelen, skal de enkelte lande forhandle om den indbyrdes grænse. Det vil for Danmarks vedkommende sige, at man efterfølgende både skal forhandle med Canada om den vestlige grænse og muligvis med Rusland om den 'nordlige' grænse, hvis kommissionen accepterer den danske indstilling til en udvidet kontinentalsokkel nord for Grønland.

På trods af disse usikkerheder er der foreløbigt ikke noget, der tyder på, at man ikke skulle kunne blive enige. Rusland har udvist interesse for at få klarlagt sine grænser i forhold til de andre Arktiske stater. Eksempelvis er den længerevarende grænsedisputs med Norge i Barentshavet for nylig blevet løst. Og hvis man sammenligner med kontroverser om kontinentalsokkelkrav i det Sydkinesiske Hav ånder al fred og idyl i Arktis. ${ }^{14}$

Formålet med ovenstående analyse har været at vise, hvordan UNCLOS har flyttet konflikten om geografisk kontrol ud af et traditionelt sikkerhedspolitik-domæne og over i et videnskabeligt domæne. Diskussionen, centreret om begrebet kartopolitik, har således illustreret et skift i den geopolitiske forståelse fra sikkerhed til videnskab. Dette skift er baseret på en tradition om naturlige grænser. Det kræver, at man via videnskaben kan få naturen til at tale med én stemme. Ovenstående har jeg diskuteret nogle af de usikkerheder, der står tilbage, når man forbliver indenfor en videnskabelig diskurs og fastholder, at geografien i princippet kan fungere som en objektiv standard for grænsedragningen. I det følgende vil vi gå til den anden del af analysen, der argumenterer for, at selvom de Arktiske stater kan samarbejde og fastlægge grænserne i fred og fordragelighed, foregår der stadig en geopolitisk kamp i Arktis. Jeg argumenterer for, at ideen om naturlige grænser, som den udspiller sig under folkeretten, konstruerer det geografiske rum på en måde, som tilgodeser staterne, men gør det sværere for de oprindelige folk, der bor i Arktis at praktisere deres livsform. Her flytter vi det analytiske fokus fra relationen mellem sikkerhed og videnskab til relationen mellem videnskab og kultur.

\section{Videnskabens Geopolitik}

Argumentet i det ovenstående er, at der er en nøje sammenhæng mellem, hvordan man tænker geografi, og hvordan man tænker geopolitik. En objektiv verdensfor- 
ståelse og en uproblematiseret forståelse af naturen som et entydigt objekt, der kan afdækkes gennem videnskaben, låser vores forståelse af, hvordan verden ser ud og begrænser vores konfliktfokus til et, der begrænser sig til relationer mellem stater. Ved at introducere begrebet kartopolitik flyttes konfliktfokus mod forskellige måder at tænke, bruge og politisere rum. Hermed når vi andet led $\mathrm{i}$ analysen, som analyserer forholdet mellem videnskab og samfundskultur.

I en af sine diskussioner om videnskabens rolle i samfundet parafraserer Bruno Latour satirisk Clausewitz' berømte udsagn: „science is politics pursued by other means" (1999a, 273). Hermed leder han os frem mod et argument om, at videnskaben ikke kun er objektiv men, at det, der fremstår som sandt, også er et resultat af politiske kampe; alliancer mellem forskere, aftagere, finansieringskilder etc. Det betyder, at alle de videnskategorier, som vi anvender til at orientere os i verden med, må betragtes som socialt konstruerede. Og det gælder også for de to grundlæggende kategorier tid og rum. Det betyder ikke, at rumbegrebet fremstår som en arbitrær størrelse, men snarere at begrebsliggørelsen af naturen spiller sammen med videnspraksis, som opstår i et samspil med geografien; for eksempel gennem kortlægning. Kort bliver i princippet fremstillet som et resultat af et møde mellem en bestemt måde at tænke og beregne rum på og mødet med de ikke-menneskelige faktorer, som skal måles. Begge faktorer har indflydelse på den rummelig virkelighed, der bliver etableret i dette netværk mellem menneskelig og ikke-menneskelige aktører.

Det betyder, at det geografiske rum aldrig er en naturlig eller given størrelse men i stedet skal forstås som et fænomen, der etableres igennem vores gensidige interaktion med vores fysiske omgivelser; både med hensyn til hvordan vi bruger - og kender til - vores omgivelser. Med et sådant perspektiv, bliver den rolle, naturen spiller i relation til vores samfundsopbygning, direkte relateret til vores måde at tilvejebringe viden om den på. Argumentet i det følgende er, at Havretskonventionen, som følge af den måde den definerer betingelserne for den naturlige grænsedragning, forudsætter en bestemt måde at interagere med det geografiske rum på. Som konsekvens heraf kan den siges at forudsætte en partikulær geografisk virkelighed, som ikke nødvendigvis harmonerer med andre livsformer. I dette tilfælde forudsætter UNCLOS en rumlig virkelighed, der er abstrakt, kan måles og beregnes ved hjælp af geometri, og opererer med en distinktion mellem hav og land.

Det nuværende internationale politiske regime baseret på suveræne territorialstater har sin rod i det 15 . århundredes politiske udvikling. Det bygger på en juridisk distinktion mellem land, der bliver underlagt suveræn kontrol, og vand, som ikke er beboet men fremstår som ressourcedepot og et transitrum (Steinberg 2001). Inuit omkring Arktis har via deres internationale interesseorganisation ICC gjort krav på en anden rumforståelse:

Life in the Arctic is dependent on movement, and [...] sea ice is integral to this movement. The Inuit have been a nomadic people living in the Arctic since ancient times: their entire culture and identity is based on free movement on the land. Inuit rely on free movement in order to eat, to obtain supplies for traditional clothing and art, and generally to keep their rich cultural heritage alive. Inuit temporarily move out from settlements to harvest resources that are sometimes bartered or traded. This movement takes place on the sea ice that surrounds and connects Inuit communities" (ICC 2008, i).

Hermed bliver is fremført som en hybrid mellem land og vand og gjort til en gyldig kategori, som ikke umiddelbart kan forenes med folkeretten. ${ }^{15}$ Netop derfor stiller ICC spørgsmålstegn ved, hvor legitimt det er, at opdele Inuit brugsland i forskellige suveræne jurisdiktioner. ICC gør opmærksom på, at mange af de områder, folkeretten betragter som hav, er befolket idet, der er tale om en geografi, som bliver brugt til transport, jagt $\mathrm{mm}$. Som konsekvens stiller de spørgsmålstegn ved de geografiske antagelser bag folkeretten. Som ICC formand Aqqaluk Lynge udtrykker det: „Der er mange juridiske ting, som vi gør levende [...] og det er måske derfor, forskellen på den gængse jura og vores forståelse af tingenes virkelige sammenhæng ikke rigtig kan følges “ ${ }^{\text {“ }}{ }^{16}$

Konkret er Inuit bekymrede for, at de Arktiske staters fokus på grænsedragning i Arktis vil gøre det sværere for Inuit at opretholde deres traditionelle livsform, hvor store dele af Arktis betragtes som fælles områder. I 2009 publicerede ICC en erklæring om suverænitet. I den forbindelse udtalte den daværende formand for ICC, Patricia Cochran, at

[o]ur declaration addresses some of these questions from the position of a people who know the Arctic intimately. We have lived here for thousands and thousands of years and by making this declaration, we are saying to those who want to use Inuit Nunaat [Inuits hjemland] for their own purposes, you must talk to us and respect our rights." 17 
Dette fremstår som et klart udtryk for en utilfredshed med den måde, det geopolitiske spil om grænsedragning $\mathrm{i}$ Arktis overser oprindelige folks tilstedeværelse i - og brug af - den arktiske geografi.

Denne konflikt om geografi får en ekstra dimension $\mathrm{i}$ sammenhæng med Grønland. På grund af Grønlands status som delvist autonom del af det danske rigsfællesskab kompliceres spørgsmålet om, hvorvidt ICCs erklæring kan ses som et oprindeligt folks modstand mod stater, hvor de er i mindretal, eller om der er noget andet på spil. I dette temanummer diskuterer både Gerhardt og Gad et al. Inuits politiske status i Arktis. I min analyse bliver denne diskussion om politisk status knyttet til et fundamentalt spørgsmål om geografi. Og spørgsmålet er, om Grønlands status som en statslignende aktør er foreneligt med ICCs kulturbaserede krav om en anden forståelse af samspillet med naturen? Umiddelbart ville det kræve, at man skulle kunne forene en anden geografiforståelse og praksis sammen med international ret, og det er svært at forestille sig, hvordan sådanne hybride kategorier ville kunne gøres kompatible med folkeretten.

Der er tydelige tegn på, at i takt med, at Grønland søger at udnytte sine råstoffer og $\mathrm{i} ø ø j e r e$ grad fokusere på økonomisk udvikling, kommer der flere konflikter mellem befolkningen og det grønlandske selvstyre. Korresponderende med ICCs generelle krav på fælles brugsret over (dele af) det arktiske område, er der ikke privat ejendomsret over land i Grønland. Man kan ikke eje land. Det er en radikal afvigelse fra, hvordan de fleste økonomier i verden fungerer, og det giver problemer i forhold til at inddrage internationale private aktører i processen med råstofudvinding. Hvordan giver man for eksempel et internationalt mineselskab ret til at udvinde ressourcer i et afgrænset område, hvis der ikke er privat ejendomsret? Og hvordan forener man befolkningens hævdvunde ret til at samle og jage det, jorden kan give, med et mineselskabs legitime interesser $\mathrm{i}$ at kræve eksklusivret til koncessionsområder? Man prøver at løse dette gennem lovgivning, men det tyder ikke umiddelbart på, at det sker tilfredsstillende. Der har allerede været en del polemik, om hvorvidt selvstyret underminerer folkets traditionelle kollektive ejerskab over jorden ved at give efterforsknings- og udvindingskoncessioner til multinationale mineselskaber. ${ }^{18}$ Fra landsstyret antyder man, at det i en vis udstrækning er nødvendigt at tilpasse sig, ${ }^{19}$ mens ICC antyder, at selvstyret er ved at sælge ud af det, Grønland har kæmpet for i mindst 30 år. $^{20}$

Spørgsmålet er naturligvis nu, i hvilken udstrækning man kan gøre videnskab, kortlægning mm eneansvarlig for den verserende konflikt. Selvom det er mere diffust end diplomatiske ytringer eller sikkerhedspolitisk prak- sis, er der ingen tvivl om, at den videnskabeligt funderede kartografi spiller en rolle i det geopolitiske spil. Den videnskabelige kortlægning er med til at producere en kartografisk virkelighed, som er blottet for referencer til mennesker og forskellige måder at bruge det geografiske rum på. På landkortet fremstår territoriet som tomt og manipulerbart. På den baggrund kan strategiske beslutninger tages i stil med: 'Her er den optimale placering for en flybase' eller 'her er der mange rubiner, så her lægger vi en mine'. I den proces overser man ofte eksisterende og alternative livsformer. Der er naturligvis ingen determinisme involveret, men der er et samspil mellem forskellige kartografier og forskellige opfattelser af, hvad der er den rigtige politik. I takt med at den kortlægningsbaserede virkelighed vinder indpas i alt fra international grænsedragning over landsplanlægning til brug af GPS til hverdagsnavigation integreres en bestemt social rumlighed på mange niveauer med politisk og hverdagspraksis. Herved forstærkes modsætningen mellem sociale rumligheder, og videnskabelig praksis spiller sin egen særegne men signifikante rolle i den proces.

\section{Konklusion}

I indledningen rejste jeg en problemstilling om geopolitik i Arktis. Hvor de fleste analyser og diskussioner om geopolitik fokuserer på relationen mellem stater, så giver det geopolitiske objektiv et helt andet billede, når man problematiserer geo-siden af geopolitik. Ved at introducere begrebet kartopolitik har jeg fokuseret på betydningen af videnskabelig praksis, som skal danne grundlag for en suverænitetsafklaring på basis af FNs Havretskonvention. Det er denne kombination af videnskab, lov, og idéen om kontinentalsokkelen som en naturlig grænse, der har gjort det muligt, at flytte spørgsmålet om territorial kontrol ud af den konventionelle geopolitiske arena og over $i$ et regime styret af rets-og kortlægningsprincipper. Det blev afdækket i analysen første del. Anden del fokuserede på, hvorfor det alligel er vigtigt at diskutere geopolitik i Arktis. Det selvsamme rets- og videnskabsregime, som muliggør fredeligt samarbejde mellem stater mht. suverænitetsafklaring, bliver en del i en - geografisk set - mere fundamental konflikt om geografi og den rumlige virkelighed. Således fokuserede anden del af analysen på den geopolitiske kamp mellem forskellige livsformer, som det kommer til udtryk i ICCs udtalelser mod folkeretten og mod det grønlandske selvstyres politik.

Den politiske løsning på den her beskrevne spænding mellem sociale geografier består ikke $i$ at tage stilling til den men derimod at anerkende, at konflikten er til stede i Arktis; at der udspiller sig en geopolitisk kamp mellem forskellige sociale geografier. Derved er det ikke 
længere muligt at afvise alternative rumopfattelser som uvidenskabelige eller mindre vigtige. Hvis naturen - med Latour - ikke længere kan iscenesættes som en objektiv baggrund for den politisk handlen, må forskellen mellem sociale geografier opfattes som politisk frem for en, der kan afgøres videnskabeligt. Modsætningen skal altså anerkendes og gøres politisk legitim.

Den overordnede pointe er således, at geopolitik handler om mere end konflikt-samarbejde mellem stater, og at selv når alle staterne går ud og siger, at de samarbejder, så er der stadig en kamp, der handler om geografi. Denne erkendelse er særligt relevant i en dansk sammenhæng, hvor det er et relativt snævert fokus, der er blevet lagt på geopolitik i Arktis. Det fortæller os, at diskussionen om geopolitikkens relevans og eventuelle tilbagekomst bliver nødt til at fokusere bredere end en snæver forståelse af politisk konkurrence mellem stater om at kontrollere vigtige ressourcer og/eller så stort et territorium som muligt. Artiklen her har argumenteret for et skift i fokus fra det traditionelt politiske til det geografiske og derved et skift mod i højere grad at koncentrere sig om, hvordan den geografi, der ligger som fundament for international politik, bliver konstrueret.

\section{Litteratur}

Agnew, JA and S Corbridge 1995, Mastering Space: hegemony, territory and international political economy, Routledge, London.

Agnew, J 2010, 'Still Trapped in Territory?' Geopolitics vol, 15, no. 4, pp. $779-784$.

Biggs, M 1999, 'Putting the State on the Map: cartography, territory, and European state formation', Comparative Studies in Society and History, vol. 41 no. 2, pp. 374-405.

Buisseret, D 1984, 'The Cartographic Definition of France's Eastern Boundary in the Early Seventeenth Century', Imago Mundi, vol 36, pp. $72-80$.

Buisseret, D 1992, Monarchs, ministers and maps the emergence of cartography as a tool of government in early modern Europe, University of Chicago Press, Chicago.

Chaturvedi, S 1996, The Polar Regions: a political geography, Wiley in association with the Scott Polar Research Institute, Chichester.

Crampton, JW 2010, 'Cartographic Calculations of Territory', Progress in Human Geography, vol. 1-12, DOI: 10.1177/0123456789123456.

Dalby, S 2010, 'Recontextualising Violence, Power and Nature: the next twenty years of critical geopolitics?' Political Geography, vol. 29, no. 5, pp. 280-288.

Dodds, K 2002, Pink ice: Britain and the South Atlantic Empire, IB Tauris, London.

Dodds, K 2010, 'Flag planting and finger pointing: The Law of the Sea, the Arctic and the political geographies of the outer continental shelf', Political Geography, vol. 29, no. 2, pp. 63-73.

Durkheim, E 1976, The Elementary Forms of the Religious Life, Allen and Unwin, London.

Elden, S 2010, 'Land, Terrain, Territory' Progress in Human Geography, DOI: 0309132510362603
Gerhardt, H, PE Steinberg et al 2010, 'Contested Sovereignty in a Changing Arctic', Annals of the association of American Geographers, vol. 100, no. 4, pp. 992-1002.

Hastrup, K 2010, Vinterens hjerte Knud Rasmussen og hans tid, Gad, København.

Ilulissat-erklæringen 2008, Arctic Ocean Conference, Ilulissat, Grønland, 27-29 maj 2008

Jensen, Ø 2008, 'Kontinentalsokkelens avgrensning utenfor 200 nautiske mil: Norske og russiske perspektiver i de nordlige havområder', Internasjonal Politikk, vol. 66, no. 4, pp. 563-590.

Joyner, CC 1991, 'Ice-covered regions in international law', Natural Resources Journal, vol. 31, pp. 213-242.

Jørgensen, HJ \& J Rahbek-Clemmensen 2009, Hold hovedet koldt, Dansk Institut for Militære Studier, København.

Latour, B 1988, The pasteurization of France, Harvard University Press, Cambridge, Mass.

Latour, B 1993, We have never been modern, Harvester Wheatsheaf, London.

Latour, B 1999a, 'Give me a laboratory and I will raise the world...' in M Biagioli (ed.) The Science Studies Reader, Routledge, London, pp. 258-76.

Latour, B 1999b, Pandora's Hope: essays on the reality of science studies, Harvard University Press, Cambridge, Mass.

Latour, B 2005, Reassembling the Social: an introduction to actor-network-theory, Oxford University Press, Oxford.

Lund, J 2007, 'At opretholde Sindets Neutralitet": Geografen Gudmund Hatt, det ny Europa og det store verdensdrama', i JT Lauridsen (red.), Over stregen - under besattelsen, Gyldendal, København.

Macnab, R 2008, 'Submarine Elevations and Ridges: wild cards in the poker game of UNCLOS article 76', Ocean Development and International Law, vol. 39, pp. 223-34.

McDorman, TL 2002, 'The role of the Commission on the Limits of the Continental Shelf: a technical body in a political world', The International Journal of Marine and Coastal Law, vol. 17, no. 3, pp. 301-24.

McIver, J 1997, 'Environmental Protection, Indigenous Rights and the Arctic Council: Rock, Paper, Scissors on the Ice', Georgetown International Environmental Law Review, vol. 10, pp. 147-168.

Ó Tuathail, G 1996, Critical Geopolitics, Routledge, London.

Olsvig, S 2010, 'Magt og Medindflydelse i Grønland', Sermitsiaq nr. 8-2010, udgivet den 26. februar.

Oude Elferink AG and DR Rothwell 2001, The law of the sea and polar maritime delimitation and jurisdiction, Nijhoff, Hague.

Petersen, N 2009, 'The Arctic as a New Arena for Danish Foreign Policy: the Ilulissat Initiative and its implications', in N Hvidt and H Mouritzen (eds.), Danish Foreign Policy Yearbook, Danish Institute of International Studies, København.

Potts, T \& C Schofield 2008, 'Current Legal Developments: the Arctic', The International Journal of Marine and Coastal Law, vol. 23 , pp. 151-76.

Powell R 2008, 'Configuring an "Arctic Commons"?' Political Geography, vol. 27, no. 8, pp. 827-32.

Proelss, A 2009, 'Governing the Arctic Ocean', Nature Geoscience no. 2 (May), pp. 310-3.

Roucek, JS 1983, 'The geopolitics of the Arctic.', American Journal of Economics and Sociology, vol. 42, no. 4, pp. 463-471.

Sahlins, P 1989, Boundaries: the making of France and Spain in the Pyrenees, University of California Press, Berkeley.

Shadian, J 2010, 'From States to Polities: Reconceptualising sovereignty through Inuit governance', European Journal of International Relations, DOI: 1354066109346887. 
Steinberg, PE 2001, The social construction of the ocean, Cambridge University Press, Cambridge.

Strandsbjerg, J 2008, 'The Cartographic Production of Territorial Space: Mapping and State Formation in Early Modern Denmark', Geopolitics, vol. 13, no. 2, pp. 335-58.

Strandsbjerg, J 2010, Territory, Globalisation and International Relations: the cartographic reality of space, Palgrave, Basingstoke.

Thrift, N 2000, 'It's the Little Things', in K Dodds \& D Atkinson (eds.) Geopolitical Traditions: a century of geopolitical thought, Routledge, London, pp. 380-387.

\section{Noter}

1. Jeg vil gerne rette en stor tak til Janus Hansen, Sara Katrine Nissen, Politiks redaktion samt den anonyme reviewer, som alle er kommet med kritiske og konstruktive forslag til forbedringer af artiklen.

2. Jeg anvender termerne Havretskonvention, FNs Havretskonvention og UNCLOS på skift. De refererer alle til United Nations Convention on the Law of the Sea. UNCLOS omtales ogsa nogle gange som LOSC (http://www.un.org/Depts/los/convention_agreements/ texts/unclos/unclos_e.pdf, sidst besøgt 11. januar 2011).

3. Der er forskellige kriterier for, hvordan ydergrænsen for den udvidede kontinentalsokkel kan beregnes. Se kontinentalsokkelprojektets hjemmeside for en forklaring af de forskellige metoder http:// a76.dk/facts/background/kontinentalsokkel.html.

4. I den sammenhæng er det værd at nævne to igangværende forskningsnetværk i Norge og Storbritannien. GeoPolitics in the High North er et større projekt finansieret af det norske forskningsråd, som følger en relativ konventionel forståelse af geopolitik, men inddrager mange temaer. Det britiske Polar Geopolitics følger en kritisk geopolitisk tilgang (http://www.geopoliticsnorth.org/index. php \& http://www.polargeopolitics.com).

5. Jeg har i løbet af efteråret 2010 foretaget ca. 15 formelle og uformelle interview med repræsentanter fra Grønlands selvstyre (embedsmænd, medlemmer af Inatsisartut (lovgivende) og Naalakkersuisut (udøvende)), ICC, den danske statsforvaltning og det danske kontinentalsokkelprojekt. Jeg henviser kun til specifikke interview ved direkte citat.

6. Se Strandsbjerg (2010) for en uddybning af denne diskussion.

7. Financial Times August 9 2007, the Economist May 162009

8. Bl.a. citeret i „Harper on Arctic: 'Use it or lose it', http://www.canada.com/topics/news/story.html?id=7ca93d97-3b26-4dd1-8d928568f9b7cc2a, sidst besøgt 23/11/2010.
9. Se f.eks. „Backgrounders: Arctic/offshore patrol ships“, http:// www.navy.forces.gc.ca/cms/3/3-a_eng.asp?id=617, sidst besøgt 26/09/2010.

10. „Canadian troops heading to Arctic after Afghan mission“, http:// www.nationalpost.com/news/Canadian+troops+heading+Arctic+af ter+Afghan+mission/3707032/story.html, sidst besøgt 23/11/2010.

11. Se artikel af Henrik Gutzon Larsen i nærværende nummer for en mere detaljeret indføring i geopolitikkens historie.

12. Det ville være mere korrekt at omtale det som geologi eller geomorfologi, men for at undgå begrebsforvirring mht. den overordnede diskussion om geopolitik og geografiens rolle beholder jeg den overordnede term geografi.

13. Den økonomiske eksklusivzone giver flere rettigheder mht fiskeri, forskning $\mathrm{mm}$. Ydermere kompliceres de juridiske omstændigheder omkring øer af, at rettighederne mindskes, når man bevæger sig ud i den udvidede zone hinsides de 200 sømil. For indeværende fokuserer jeg på råstoffer, fordi det er dynamikken og logikken i samspillet mellem loven og geografien, som er det centrale her.

14. Sammenlign for eksempel med Kinas totale afvisning af Malaysias og Vietnams kravi det Sydkinesiske Hav, http://www.un.org/Depts/ los/clcs_new/submissions_files/submission_mysvnm_33_2009. htm, sidst beøgt 24/11/2010.

15. Is har en uklar status i folkeretten men jvf. Christopher C. Joyner så skal havis utvetydigt betragtes som havområde (1991, 224). Se også (Gerhardt, Steinberg et al. 2010) som argumenterer for en sammenhæng mellem den materielle geografis uklare status og de mange uafklarede suverænitetsspørgsmål, som findes i Arktis.

16. Interview med ICC Chair Aqqaluk Lynge, Nuuk, Grønland, $18 / 11 / 2010$

17. April 292009 http://northernwaterways.com/news/?p=1323, sidst besøgt 24/11/2010.

18. Der var for eksempel en sag i 2007 , hvor en gruppe af rubinsamlere blev bortvist af myndighederne. Det rejste efterfølgende debat om inuits rettigheder til landets ressourcer i forhold til den måde, råstofferne bliver håndteret på af Råstofdirektoratet under Grønlands selvstyre (se for eksempel Sermitsiaq, uge 34, 2007. Se også kronik af Sara Olsvig (2010) som rejser en lignende problemstilling).

19. Interview med landsstyreformand Kuupik Kleist, Nuuk Grønland, $18 / 11 / 2010$.

20. Interview med ICC Chair Aqqaluk Lynge, Nuuk, Grønland, $18 / 11 / 2010$ 